\title{
A Study on Entrepreneurial Orientation and Startup Performance: Mediating Effect of Strategic Orientation
}

\author{
Yunsoo Shim ${ }^{1}$, Jounghae Seo ${ }^{2}$ \\ ${ }^{1}$ Graduate Student, School of Business Administration, Kyungpook National University, KOREA \\ ${ }^{2}$ Professor, School of Business Administration, Kyungpook National University, KOREA
}

\begin{abstract}
Background/Objectives: These This study aims at examining the effect of strategic orientation and entrepreneurial orientation on startup performance. Methods/Statistical analysis: Accordingly, the effect of entrepreneurial orientation on startup performance and the relationship between and roles of two elements that consist of strategic orientation were studied. Empirical research on 122 startup as residents of startup support institutions was conducted. The suitability of the research model was evaluated with the PLS-based structural equation modeling. Findings: As a result of empirical analysis, First, confirmed that entrepreneurial orientation has been verified to have a positive effect on strategic orientation. second, it was found that technology orientation did not play a mediating role in the relationship between entrepreneurial orientation and firm performance. Finally, it was confirmed that marketing orientation mediated the relationship between entrepreneurial orientation and firm performance. Improvements/Applications: This study is expected to provide entrepreneurial orientation research for startups and implications for practitioners.
\end{abstract}

\section{Index Terms}

Startup, Entrepreneurial Orientation, Strategic Orientation, Technology Orientation, Marketing Orientation, startup performance.

\footnotetext{
Corresponding author : Jeonghae Seo

johseo@knu.ac.kr

- Manuscript received November 2, 2019.

- Revised November 27, 2019 ; Accepted December 3, 2019.

- Date of publication December 31, 2019.

(c) The Academic Society of Convergence Science Inc.

2546-1583 @ 2017 IJEMR. Personal use is permitted, but republication/redistribution requires IJEMR permission.
} 


\section{INTRODUCTION}

Corporations are more in need of the transition to a method of pursuing innovativeness in addition to traditional operations and management centering on efficiency to maintain a competitive advantage. Increasingly, startups are faced with the rapidly changing technological revolution, globalization and external environmental challenges of numerous competitors (Cheng, 2014). In this situation, the life cycle of the knowledge, skills, and competencies corporations possess becomes shortened. Accordingly, companies must utilize various competencies and knowledge to solve problems, with the search for a source of competitiveness becoming more urgent and pressing than ever before. The vast majority of startups are more vulnerable than existing firms in numerous aspects including external factors such as economic recession and excessive competition and internal factors like lack of strategy and necessary resources (Kim, 2007). In addition, strategic direction is important because startups prioritize survival the highest via the creation of performance (Madsen, 2013).

Entrepreneurial orientation is the entrepreneurial process method about how to manage an organization for growth after its establishment(Lumpkin \& Dess, 1996; Chang \& Lim, 2005). Since the establishment of a company, entrepreneurial orientation at the organizational level embodied in the organization can play an important role in the growth and maintenance of the organization (Yoon, 2014). In the case of startups, because the decision-making authority of an entrepreneur is relatively high. Thus, the strategic direction of an entrepreneur significantly impacts firm activity. Moreover, startups must develop innovative technologies and services in order to overcome limited resources in the process of pioneering new products and markets. At the same time, startups are required to consider heightening their competitiveness in diverse aspects including understanding customer needs, active response to competitor information, technologies development and applications, and communication between functions. Thus, despite the importance of the two dimensions of strategic orientation including technology orientation (Gatignon \& Xuereb, 1997), which seeks to acquire superior technological advances over competitors, and marketing orientation (Slater \& Naver, 1995), which seeks to understand as well as satisfy customers, research of comprehensive analysis on the effects of entrepreneurial orientation and strategic orientation is lacking.

In this study, first, the direct impact of entrepreneurial orientation on startup performance is confirmed. Then, this study aims at confirming the respective mediating effect of technology orientation and marketing orientation, two dimensions constituting strategic orientation that can enhance their effectiveness. In order to verify the suitability of the research model, this study utilizes a structural equation model to confirm the reliability and validity, followed by an evaluation of the significance of the hypothesis via path analysis. The results of this study are expected to provide implications for improving the performance of startups and expanding and securing the growth foundation.

\section{CONCEPTUAL FRAMEWORK}

\section{A. Entrepreneurial Orientation}

The entrepreneurial orientation is a critical and essential important factor in firm strategy establishment and decision making and has been used as a research framework to explain firm mindsets (Dess et al., 1997). It refers to characteristics from an organizational perspective that takes risks and emphasizes innovation to seize opportunities in the market and stay ahead of competitors (Miller \& Friesen, 1983), as well as the actions of developing and pursuing innovative services for differentiation against other companies in the market and the process of decision-making thereof (Lumpkin \& Dess, 1996). The entrepreneurial orientation is classified into 3 categories of innovativeness, proactiveness, and risktaking, and numerous studies use the classification by Miller(1983) (Covin \& Slevin, 1990; Zahra \& Covin, 1995, Covin \& Wales, 2010)

1. Innovativeness.

Innovativeness is elements related to innovations such as new products, new services, new experiences, and process development. Innovativeness is a key construct of entrepreneurial orientation and means the need for a company including bold and wideranging actions taken to achieve company goals (Miller, 1983). Lumpkin \& Dess (1996) said innovativeness is the will to encourage creativity, such as new experiences, technical leadership, and new process development, while Lee et al. (2006) have defined innovativeness as an active attitude for solving problems and ability to develop new process products and new services via creative ideas.

\section{Proactiveness}

The tendency of discovering opportunities in the market, sensing trends in firm environment changes, and making strategic decisions with a progressive perspective is proactiveness (Miller, 1983). In addition, Lyon et al. (2000) defined proactiveness as a tendency of a corporation of releasing new products and services to the market ahead of its 
competitors, based on which it preoccupies the market and becomes a leader. Lumpkin \& Dess (1996) said that proactiveness is the propensity of fulfilling a role as a leader who can forecast demand according to the market situation and lead the market, while Wiklund \& Shepherd (2005) defined proactiveness the tendency of an organization of brightening the future prospect and pursuing an aggressive search for market entry or competition strategy over competitors. In addition, because proactive companies prefer to be leaders to seize new opportunities, based on which they can obtain pioneering benefits such as higher prices and competitive advantages, more efforts are said to be invested by the management of a progressive corporation to create more market opportunities(Lumpkin \& Dess, 1996; Zahra \& Covin, 1995; Keh et al., 2002).

3. Risk-taking

Risk-taking reflects the willingness of a corporation to invest more resources into $\mathrm{R} \& \mathrm{D}$ or projects, even assuming uncertain performance and probability of failure(Miller \& Friesen, 1978; Lumpkin \& Dess, 2001). Miller \& Friesen (1983) referred to risk-taking as the willingness to invest more resources in businesses of which failure costs are large. In addition, Lumpkin \& Dess (1996) defined risk-taking as the tendency of favoring options that can be strategically more successful, even with some risks, in terms of achieving the organization's goals, while Keh et al. (2002) said risk-taking is the willingness to accept the already calculated business risks and to invest important resources notwithstanding the severe uncertainty of the results. In general, corporations with high-risk taking tend to prefer risk-taking to achieve organizational goals, even if the strategy includes a high level of risk(Lumpkin \& Dess, 1996).

\section{B. Entrepreneurial Orientation and Performance}

As entrepreneurial orientation is known as improving firm performance(Zahra \& Covin, 1995; Wiklund \& Shepherd, 2005), Wiklund \& Shpherd (2003) confirmed that entrepreneurial orientation strengthens the relationship between firm knowledge resources and performance. Naman \& Slevin (1993) consider entrepreneurial orientation as increasing performance only when organizational structures and strategies are proper. Lumpkin \& Dess (1996) also discovered that the impact of entrepreneurial orientation on firm performance differs according to the environment of the corporation, if the market is uncertain, it further increases firm performance (Dimitratos et al., 2004). Thus, in this study, the following hypothesis was established in relation to the entrepreneurial orientation and performance of startups.
Hypothesis1: There is a positive relationship between Entrepreneurial Orientation and firm performance.

\section{Entrepreneurial Orientation and Strategic Orientation}

Strategic orientation means a consistent set of guidelines and modalities for firm decision-making, which are used for policy and procedure establishment and resource allocation (Hambrick, 1984). It is defined as the strategic direction of creative behaviors of a corporation that helps it to achieve excellent management performance (Gatignon and Xuereb, 1997; Narver and Slater, 1990), while it is about the method of using strategies to adapt to changing environments (Manu and Sriram, 1996) as well as a guideline that affects the marketing and strategy-making activities of a corporation (Noble et al., 2002). In this study, strategic orientation is classified into technology orientation and marketing orientation according to the classification by Gatignon and Xuereb (1997).

Technology orientation is a firm capability trying to continuously secure technological background used for new products (Cooper, 1984), and is a technology-oriented firm culture that emphasizes new technologies in order to obtain superior technology over its competitors. Technology orientation achieves a technological advantage that cannot be easily copied by competitors and provides companies the potential for gaining greater competitive advantage (Jeong et al., 2006). Moreover, technology orientation includes an organizational culture where companies adopt innovative technologies to secure a sustainable competitive advantage in the market and strive to settle the technologies within the organization. This includes using cutting-edge technologies in new product development, increasing the speed of the integration of new technologies, and pursuing new technology development and new product idea generation. Corporations need a strong technology orientation in order to increase their technological capabilities and investment in development for creating innovations of superiority over their competitors. In markets where demand is relatively uncertain, technology orientation must be strengthened to achieve firm performance(Gatignon and Xuereb, 1997).

The marketing orientation is the activity of an information process that generates and spreads information on customer needs, based on which strategic responses are presented (Kohli and Jaworski, 1990). It is the tendency of an organization of considering competitors in the market and prioritizing customer satisfaction, referring to the 
technology and capability to understand and satisfy customers. Marketing orientation includes valuable information generation about customers and competitors, the ability of a company in disseminating information and turning it into useful information, and the coordination of the resources amongst departments to create the best customer value (Day, 1994). Also, it is a firm culture that constantly provides superior performance to corporations by creating effective and efficient behaviors for the creation of buyer value. Based on marketing orientation, information about customers and competitors is collected, the information is distributed and spread within the organization, and customer value is created while responses to competitors are made via cross-departmental collaboration based on information (Slater \& Naver, 1995). Marketing orientation is classified into 3 dimensions of customer orientation of the attitude and behavior of trying to provide customer satisfaction effectively by defining the needs from the customer's perspective, competitor orientation, which is the tendency of an organization that prepares against competitors by identifying the external opportunities and threats as well as strengths and weaknesses internally, and the internal coordination among internal departments, which is the behaviors of coordinating and cooperating with each other to generate values and fulfill customer needs based on the information gathered about competitors and customers.

The relationship between the entrepreneurial orientation and the technology orientation shows that the higher the entrepreneurial orientation, the stronger the technological innovation process and activities, which helps secure and develop a technological competitive advantage that differentiate a corporation against its competitors and combine the developed resources efficiently before competitors by identifying suitable resources for the technology innovation process (Burgelman et al. 2004). In terms of the relationship between entrepreneurial orientation and marketing orientation, entrepreneurial orientation positively affects marketing orientation (Matsuno et al, 2002; Weerawardena, 2003), and the degree of risk aversion of top management has an effect on marketing orientation (Kohli \& Jaworski, 1990). Accordingly, in this study, the following hypotheses were set for entrepreneurial orientation and strategic orientation of startup.

Hypothesis2: There is a positive relationship Entrepreneurial Orientation and Technology Orientation.

Hypothesis3: There is a positive relationship between Entrepreneurial Orientation and Marketing Orientation.

\section{Mediating Effect of Strategic orientation}

The entrepreneurial orientation emphasizes the tendency of pursuing innovation of a corporation (Schumpeter, 1934) and influences strategic attitudes based on management activities that newly and aggressively make attempts in addition to the new technology innovation in product production (Zahra, 1993). In order to overcome the limited resources and conditions of a corporation, technology orientation is supported as a growth engine that can strengthen rapid technological innovation activities and secure a competitive advantage for differentiating from existing market competitors in a short period of time. Technology orientation is the capability of a corporation of continually securing a competitive edge in technology, providing a technological advantage that cannot be easily copied by the competition, providing companies the potential to gain greater competitive advantage, and having positive effects on new product performance (Jeong et a1., 2006). The entrepreneurial orientation can maximize performance because it can develop new products of higher quality via technology orientation and can secure competitive potential innovation performance based on competitive intellectual property rights. Furthermore, when it is difficult to identify potential customers who are not visible, companies strive to actively respond to the rapidly changing environment in order to fulfill customer needs and capture and secure niche markets based on entrepreneurial orientation (Slater and Narver, 1995). The marketing orientation is about pursuing technologies and abilities that understand as well as satisfy customers. It identifies competitors' long-term strategies and abilities confirms technologies that can fulfill customer needs, as well as analyzes customers and establishes a marketing strategy for a company for meeting the current needs. As such, marketing orientation is a factor that enables the generation of competitive advantage of a company in terms of function and quality, which leads to a performance by quickly obtaining a competitive advantage in products or services in the market (Cooper, 1994). Numerous studies have found that marketing orientation has a positive effect on firm performance (Baker \& Sinkula, 1999; Jaworski \& Kohli, 1993; Li et al., 2008). Accordingly, this study set the following hypotheses on the entrepreneurial orientation and strategic orientation of startups.

Hypothesis4: Technology Orientation will mediate the relationships between entrepreneurial orientation and firm performance. 
Hypothesis5: Marketing Orientation will mediate the relationships between entrepreneurial orientation and firm performance.

$\mathrm{H} 3$

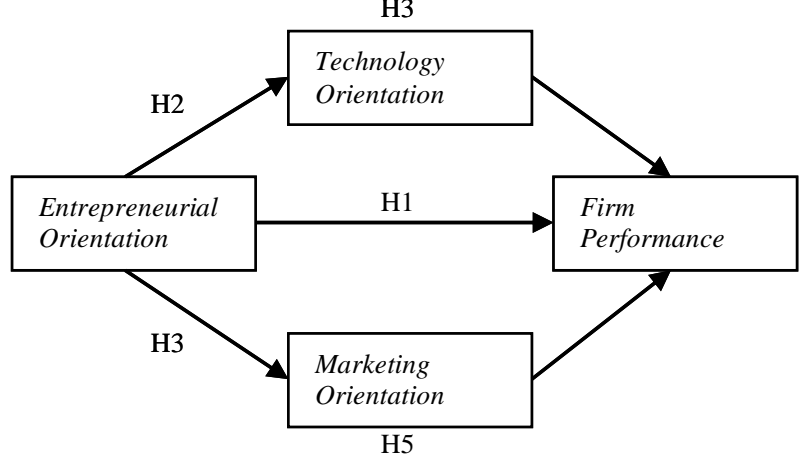

Fig. 1. Conceptual model

\section{RESEARCH DESIGN}

\section{A. Sample}

By obtaining the firm information of a total of 746 companies via matching the list of Korean startup support organizations with the data on the startup portal site, the survey was conducted for about 2 months from April 2017. In addition, the purpose and contents of the study were explained via e-mail or calls, in addition to personal visits were made as needed to collect the responses. Of the total 158 corporations that responded to the survey, the final 122 companies were selected as the empirical analysis sample after excluding companies that have been existed for more than 7 years.

For statistical analysis, the Partial Least Squaresbased structural equation model was utilized, and, for the hypotheses verification, path analysis was used after evaluating the suitability of the measurement model and structural model with the SmartPLS 3.0 program. PLS-SEM is a nonparametric approach that does not assume multivariate normality, enabling the simultaneous measurement of the validity of complex causal models and the measurement of variable paths and explanatory power (Chin, 1998; Bae, 2015). PLS-SEM has been widely used in recent startup research because it is suitable for exploratory research for the prediction of latent variables and the development of theories (Park \& Sung, 2016).

Table 1. Caracteristics of SAmple Startup(N=122)

\begin{tabular}{clll}
\hline \hline Construct & Classification & Frequency & $\%$ \\
\hline Firm Age & $1-2$ & 59 & 48.4 \\
& $3-4$ & 44 & 36.1 \\
Firm Size & $5-6$ & 19 & 15.6 \\
& $2-4$ & 44 & 36.1 \\
& $5-9$ & 39 & 32.0 \\
& $10-14$ & 18 & 14.8 \\
& $15-19$ & 9 & 7.4
\end{tabular}

\begin{tabular}{llll} 
& $20-$ & 12 & 9.8 \\
Developme & Founding & 27 & 22.1 \\
ntal stage & Commercializati & 78 & 63.9 \\
& on & 11 & 9.0 \\
& Growth & 3 & 2.5 \\
& Mature & 3 & 2.5 \\
& Decline & & \\
\hline \hline
\end{tabular}

\section{B. Measure}

In order to identify the direct effects of entrepreneurial orientation on firm performance and the mediating effect of strategic orientation, variables are measured based on relevant studies, and all variables used in the empirical analysis are measured by the Likert 5-point scale

\section{Entrepreneurship Orientation}

The entrepreneurial orientation is a critical factor in firm strategy and decision making and has been used as a framework for the research of explaining firm mindsets (Dess et al., 1997). It refers to the characteristics of an organizational perspective that takes risks and emphasizes innovation to seize opportunities in the market and stay ahead of competitors (Miller \& Friesen, 1983), in addition to the behavior of developing innovative service that differentiates a corporation from other corporations in the market and the decision-making process thereof (Lumpkin \& Dess, 1996). In addition, the entrepreneurial orientation also plays an essential role in creating a sustainable competitive advantage for a company, as presented by the Resource-Based View (RBV). Entrepreneurial orientation, for instance, can be understood as an intangible culture internalized by the management or employees within a company, which recognizes the direction of the correct setting and execution of firm goals from the resource-based perspective (RBV). The unique intangible resources possessed by corporations also serve as a source of competitive advantage as they are difficult for competitors to imitate and exhibit rare properties (Barney, 1991). The classification by Miller (1983), which is often used in numerous studies, classifies the entrepreneurial orientation into three categories of innovativeness, proactiveness, and risk-taking. Also, in reference to the study by Covin \& Slevin (1989), which is mostly used by researchers in the field, this study measured a total of 9 questions for the measurement.

2. Technology Orientation

Technology orientation is defined as a technologyoriented behavior or technology-oriented decisionmaking process that constantly strives to introduce and develop innovative technologies in order to secure technological advances and competitive advantages that are superior to competitors (Gatignon \& Xuereb, 1997). As detailed items, this study referred to the research by Zhou et al. (2005) and $\mathrm{Ji}$ et al. (2009) and used 4 items for the 
measurement on a single-dimensional scale, including the speed of new technology integration, the pursuit of new technology development, and the use of cutting-edge technology in new product development. The definition of marketing orientation is collecting and disseminating information on customers and competitors within the organization, generating customer value and responding to competitors via inter-department collaborations based on the information (Narver \& Slater, 1990). The detailed items were measured in a total of 15 questions by referring to the research by Narver \& Slater (1990) and Kohli et al. (1993), using 3 items of customer orientation, competitor orientation, and mutual coordination among internal departments. For the network, it was measured with 4 items of work/non-work related contact frequency and strength in terms of the strength of connection and network combination by referring to the research by De Clercq et al. (2009) and Tsai \& Ghoshal (1998).

3. Performance of Startup

For entrepreneurial orientation performance, diverse types of dependent variables are being used other than financial performance and innovation performance, and perceived performance is measured in many studies (De Clercq et al., 2013; Stam \& Elfring, 2008; Wiklund \& Shepherd, 2003). This study, in reference to the studies by Lee (2012) and Hult \& Ketchen (2001), composed 4 items of market share, sales, return on investment, and production efficiency within 3 years compared to the competitors, and the startup performance was measured by combining perceived financial performance and perceived non-financial performance.

4. Control Variable

In order to control the influence factors on startup performance, this study used company size, company age, and growth-stage as control variables. It was applied in order to control the effect of company size, company age, and growth stages on the performance via the resources and organizational structure of the company (Jang, 2006).

\section{ANALYSIS AND RESUlts}

\section{A. Assessing Measurement Model}

For the evaluation of the measurement model of PLS-SEM, the internal consistency reliability, convergent validity, and discriminant validity were evaluated (Shin, 2018), of which results are summarized in <Table 2>. The internal consistency reliability was found to satisfy both Cronbach's $\alpha$ and the composite reliability at the conformance criterion of 0.6 or higher as well as and rho_A ( $\left.\rho_{-} A\right)$ with the conformance criteria of 0.7 or higher. Also, the outer loading relevance was found to satisfy the conformance criteria of 0.7 or higher as well as the AVE value of 0.5 or higher (Hair et al., 2011; Fornell \& Larcker, 1981).

Table 2. CONSTRUCT RELIABILITY AND VALIDITY

\begin{tabular}{llcccc}
\hline \hline & \multicolumn{2}{c}{$\begin{array}{c}\text { Internal Consistency } \\
\text { Reliability }\end{array}$} & \multicolumn{2}{c}{ Validity } \\
Construct & $\begin{array}{l}\text { Cronb } \\
\text { ach's } \\
\text { Alpha }\end{array}$ & P_A & CR & $\begin{array}{c}\text { Outer } \\
\text { loading }\end{array}$ & AVE \\
\hline Entrepreneurial & 0.845 & 0.852 & 0.896 & 0.902 & 0.684 \\
Orientation & & & & 0.822 & \\
& & & & 0.856 & \\
Technology & 0.886 & 0.899 & 0.921 & 0.898 & 0.745 \\
Orientation & & & & 0.873 & \\
& & & & 0.826 & \\
Market & 0.819 & 0.832 & 0.859 & 0.829 & 0.733 \\
Orientation & & & & 0.880 & \\
& & & & 0.901 & \\
Firm & 0.921 & 0.930 & 0.944 & 0.909 & 0.808 \\
performance & & & & 0.925 & \\
& & & & 0.858 & \\
\hline \hline
\end{tabular}

In addition, as a result of the comparison of the correlation between each AVE square root and variables to evaluate the discriminant validity, as shown in <Table 3>, the AVE square root value of each variable represented in the diagonal was found to be larger than the highest value among the correlations between the variables. (Fornell \& Larcker, 1981). As such, the above 3 results confirmed that both the reliability and validity of the measurement model were secured.

Table 3. DISCRIMINANT VALIDITY(FORNELL-LARCKER CRITERION)

\begin{tabular}{lcccc}
\hline \hline \multicolumn{1}{c}{ Construct } & $\mathbf{1}$ & $\mathbf{2}$ & $\mathbf{3}$ & $\mathbf{4}$ \\
\hline $\begin{array}{l}\text { Entrepreneurial } \\
\text { Orientation }\end{array}$ & $\mathbf{0 . 8 6 3}$ & & & \\
$\begin{array}{l}\text { Technology } \\
\text { Orientation }\end{array}$ & 0.604 & $\mathbf{0 . 8 5 6}$ & & \\
Marketing Orientation & 0.474 & 0.674 & $\mathbf{0 . 8 2 7}$ & \\
Firm performance & 0.350 & 0.597 & 0.421 & $\mathbf{0 . 8 9 9}$ \\
\hline \hline
\end{tabular}

\section{B. Assessing Structural Model: Hypotheses testing}

The PLS-SEM performs a Bootstrapping procedure in order to verify the significance of the coefficients. The $t$ value is calculated by a repetitive regression process that restores and extracts a large number of Bootstrap samples, based on which the significance and suitability of the path coefficient can be evaluated (Tenenhaus et al., 2005). As such, 5,000 Bootstrap Resampling samples were set with 122 raw data (Bae, 2015). Then, after calculating the $t$-value, the results of the verification results of the statistical significance of the hypotheses are presented in <Table 4$\rangle$. The hypotheses verification results confirmed that $\mathrm{H} 1$, which assumed that entrepreneurial orientation will have a positive effect 
on firm performance, was supported at the significance level of 0.000 , as well as that $\mathrm{H} 2$ and $\mathrm{H} 3$, which stated that entrepreneurial orientation will have a positive effect on strategic orientation, were supported at the p-value of 0.018 and 0.000 , respectively. In the case of $\mathrm{H} 4$, which indicated that technology orientation will mediate the relationship between entrepreneurial orientation and firm performance, was shown not to have a significant effect, while H5, which assumed that marketing orientation will mediate the relationship between entrepreneurial orientation and firm performance, was supported at a significance level of 0.009 .

Table 4. Path Coefficients And T-value

\begin{tabular}{|c|c|c|c|c|c|}
\hline & Hyphothesis & $\beta$ & $\begin{array}{c}\mathbf{T} \\
\text { value }\end{array}$ & $\begin{array}{c}\mathbf{P} \\
\text { value } \\
\end{array}$ & Result \\
\hline $\mathrm{H} 1$ & $\begin{array}{c}\text { Entrepreneurial } \\
\text { Orientation } \rightarrow \\
\text { firm } \\
\text { performance }\end{array}$ & 0.564 & 4.912 & $0.000 * *$ & Accept \\
\hline $\mathrm{H} 2$ & $\begin{array}{c}\text { Entrepreneurial } \\
\text { Orientation } \rightarrow \\
\text { Technology } \\
\text { Orientation }\end{array}$ & 0.134 & 2.348 & $0.018^{*}$ & Accept \\
\hline H3 & $\begin{array}{c}\text { Entrepreneurial } \\
\text { Orientation } \rightarrow \\
\text { Market } \\
\text { Orientation }\end{array}$ & 0.610 & 5.491 & $0.000 * *$ & Accept \\
\hline $\mathrm{H} 4$ & $\begin{array}{c}\text { Entrepreneurial } \\
\text { Orientation } \\
\rightarrow \text { Technology } \\
\text { Orientation } \rightarrow \\
\text { firm } \\
\text { performance }\end{array}$ & -0.042 & 0.209 & 0.835 & - \\
\hline H5 & $\begin{array}{c}\text { Entrepreneurial } \\
\text { Orientation } \rightarrow \\
\text { Market } \\
\text { Orientation } \rightarrow \\
\text { firm } \\
\text { performance }\end{array}$ & 0.264 & 2.626 & $0.009 *$ & Accept \\
\hline$* \mathrm{p}<$ & $05, * * \mathrm{p}<0.01$ & & & & \\
\hline
\end{tabular}

\section{ANALySIS AND Results}

This study focuses on the importance of strategic orientation, which is organizational culture and behavioral direction, in the process of developing new technologies and markets in order to generate and maintain a continuous competitive advantage for startups. In order to conduct in-depth research on the influence of strategic orientation on entrepreneurial orientation having an influence on startup performance, the mediating effect was analyzed by subdividing each into sub-factors of technology orientation and marketing orientation.

The results of the study first confirmed that entrepreneurial orientation has a positive effect on firm performance. Second, entrepreneurial orientation has been verified to have a positive effect on technology orientation and marketing orientation.
Third, it was found that technology orientation did not play a mediating role in the relationship between entrepreneurial orientation and firm performance. Finally, it was confirmed that marketing orientation mediated the relationship between entrepreneurial orientation and firm performance.

These results support the result of an existing study that found that entrepreneurial orientation had a positive effect on firm performance (Zahra \& Covin, 1995; Wiklund \& Shepherd, 2005), as well as that entrepreneurial orientation positively influenced strategic orientation. (Kohli \& Jaworski, 1990; Matsuno et al, 2002; Weerawardena, 2003; Burgelman et al. 2004). Based on the result of market orientation mediating the relationship between entrepreneurial orientation and firm performance, it can be determined that, because startups are in the early stages of a company, they can continuously obtain and maintain competitive advantage when they gather information on customers and competitors, disseminate the information within the organization, and establish and improve a firm culture that responds to competitors and creates customer values via interdepartment collaboration. However, the failure of technology orientation to mediate the relationship between entrepreneurial orientation and performance implies that a startup, as a newly established company, may put itself at risk with excessive technology orientation due to the lack of internal capacity and capital, which are relatively insufficient than those of middle-standing enterprises. Thus, it is necessary to make efforts to strengthen and maintain the competitiveness of startups by introducing systems at the national level such as technology protection of startups, policy support, deregulation, mentoring, and establishment of technology cooperation plans in order to enable startups to have technological competitiveness.

This study is limited in the following ways. Due to the lack of existing studies with comprehensive research on the entrepreneurial and strategic orientation of startups, the theoretical basis is somewhat insufficient. Also, because there is a limited number of startups that produce specific results, the number of samples for statistical analysis is limited. In addition, this study interpreted the results of the analysis of the cross-sectional data collected in the single year of 2017. Thus, there is a possibility of common method bias, which causes the correlation between variables to be exaggerated for measurement than the actual variance, as all of the independent variables and dependent variables of the proposed research model were measured in the form of self-report by the same respondents. Also, strategic orientation was divided into technology 
orientation and marketing orientation for more indepth study; however, no definite clarification of the result that technology orientation did not mediate between entrepreneurial orientation and performance could be made. Accordingly, future studies should examine whether the sub-factors can influence each other independently by considering the multidimensional perspectives on sub-factors constituting technology orientation. On the other hand, this study did not conduct the analysis of characteristics by type of industry. Thus, there is a need for further research that conducts multidimensional analysis and analysis of differences by industry.

\section{REFERENCES}

[1] Bae(2015). Analyses of Moderating and Mediating Effects with SPSS/Amos/LISREL/SmartPLS, Chungram Publishing, $1-619$.

[2] Burgelman, R. A., Christensen, C. M., \& Wheelwright, S.C.(2004). Strategic Management of Technology and Innovation, NY: McGraw-Hill.

[3] Chang \& Lim(2005). A Study on the Relationships between EO(Entrepreneurial Orientation) and the Success of Venture Creation, The Korean Academic Association of Business Administration, 18(3), 1121-1143.

[4] Cheng, S.(2014). Potential Lending Discrimination? Insights from Small Business Financing and New Venture Survival. Journal of Small Business Management.

[5] Chin, W. W.(1998). The partial least squares approach to structural equation modeling, Modern Methods for Business Research, 295(2), 295-336.

[6] Cooper, R. G.(1984). The Strategy-Performance Link in Product Innovation, R\&D Management, 14(8), 247-259.

[7] Covin, J. G., \& Slevin, D. P.(1989). Strategic management of small firms in hostile and benign environments, Strategic management journal, 10(1), 75-87.

[8] Covin, J. G., \& Slevin, D. P.(1990). New venture strategic posture, structure, and performance: An industry life cycle analysis. Journal of business venturing, 5(2), 123-135.

[9] Covin, J. G., \& Wales, W. J.(2010). 2012 (forthcoming). The measurement of entrepreneurial orientation. Entrepreneurship Theory and Practice.

[10] Day, G. S.(1994). The capabilities of market-driven organizations. The Journal of Marketing, 37-52.

[11] De Clercq, D., Thongpapanl, N., \& Dimov, D.(2009). When good conflict gets better and bad conflict becomes worse: The role of social capital in the conflict-innovation relationship. Journal of the Academy of Marketing Science, 37(3), 283-297.

[12] Dess, G. G., Lumpkin, G. T., \& Covin, J. G.(1997). Entrepreneurial strategy making and firm performance: Tests of contingency and configurational models. Strategic management journal, 677-695

[13] Dimitratos, P., Lioukas, S., \& Carter, S.(2004). The relationship between entrepreneurship and international performance: the importance of domestic environment. International Business Review, 13(1), 19-41.

[14] Fornell, C., \& Larcker, D. F.(1981). Evaluating structural equation models with unobservable variables and measurement error. Journal of marketing research, 39-50.

[15] Gatignon, H., \& Xuereb, J. M.(1997). Strategic orientation of the firm and new product performance. Journal of marketing research, 77-90.

[16] Hambrick, D. C. 1984. Taxonomic approaches to studying strategy: Some conceptual and methodological issues. Journal of management, 10(1), 27-41.
[17] Hult, G. T. M., \& Ketchen, D. J.(2001). Does market orientation matter?: A test of the relationship between positional advantage and performance, Strategic Management Journal, 22(9), 899-906.

[18] Jaworski, B. J., \& Kohli, A. K.(1993). Market orientation: antecedents and consequences. The Journal of marketing, 53-70.

[19] Jeong, I., Pae, J. H. \& Zhou, D.(2006). Antecedents and consequences of the strategic orientations in new product development: The case of Chinese manufacturers, Industrial Marketing Management, 35(3), 348-358.

[20] Keh, H. T., Foo, M. D., \& Lim, B. C.(2002). Opportunity evaluation under risky conditions: The cognitive processes of entrepreneurs. Entrepreneurship theory and practice, 27(2), $125-148$.

[21] Kim(2007). Top management team social capital and its impacts on firm exit from the KOSDAQ market : Evidence from venture startup companies, Journal of Strategic Management, 10(2), 71-89.

[22] Kohli, A. K., \& Jaworski, B. J.(1990). Market orientation: the construct, research propositions, and managerial implications. The Journal of Marketing, 1-18.

[23] Kohli, A. K., Jaworski, B. J., \& Kumar, A.(1993). MARKOR: a measure of market orientation. Journal of Marketing research, 467-477.

[24] Li, T., \& Calantone, R. J.(1998). The impact of market knowledge competence on new product advantage: conceptualization and empirical examination. The Journal of Marketing, 13-29.

[25] Li, Y., Zhao, Y., Tan, J., \& Liu, Y.(2008). Moderating effects of entrepreneurial orientation on market orientation-performance linkage: Evidence from Chinese small firms. Journal of small business management, 46(1), 113-133.

[26] Lumpkin, G. T., \& Dess, G. G. (1996). Clarifying the entrepreneurial orientation construct and linking it to performance. Academy of management Review, 21(1), 135172.

[27] Lumpkin, G. T., \& Dess, G. G.(2001). Linking two dimensions of entrepreneurial orientation to firm performance: The moderating role of environment and industry life cycle. Journal of business venturing, 16(5), 429451.

[28] Lyon, D. W., Lumpkin, G. T., \& Dess, G. G.(2000). Enhancing entrepreneurial orientation research: Operationalizing and measuring a key strategic decision making process. Journal of management, 26(5), 1055-1085.

[29] Madsen, T. K. (2013). Early and rapidly internationalizing ventures: similarities and differences between classifications based on the original international new venture and born global literatures. Journal of International Entrepreneurship, $11(1), 65-79$

[30] Manu, F. A., \& Sriram, V.(1996). Innovation, marketing strategy, environment, and performance. Journal of business Research, 35(1), 79-91.

[31] Miller, D.(1983). The correlates of entrepreneurship in three types of firms. Management science, 29(7), 770-791.

[32] Matsuno, K., Mentzer, J. T., \& Özsomer, A.(2002). The effects of entrepreneurial proclivity and market orientation on business performance. Journal of marketing, 66(3), 18-32.

[33] Naman, J. L., \& Slevin, D. P.(1993). Entrepreneurship and the concept of fit: A model and empirical tests. Strategic management journal, 14(2), 137-153.

[34] Narver, J. C., \& Slater, S. F.(1990). The effect of a market orientation on business profitability. The Journal of marketing, 20-35.

[35] Noble, C. H., R. Sinha, and A. Kumar(2002). Market orientation and alternative strategic orientations : A longitudinal assessment of performance implications, Journal of Marketing, 66, 25-39.

[36] Park, Sung(2016). The Effect of Entrepreneurs' Social Network on Entrepreneurial Performance : Focusing on Moderating effect of Entrepreneurial Experience", Asia- 
Pacific Journal of Business Venturing and Entrepreneurship, $11(3), 87-96$.

[37] Slater, S. F., \& Narver, J. C.(1998). Customer-led and market-oriented: let's not confuse the two. Strategic management journal, 19(10), 1001-1006.

[38] Stam, W., \& Elfring, T.(2008). Entrepreneurial orientation and new venture performance: The moderating role of intraand extraindustry social capital, Academy of Management Journal, 51(1), 97-111.

[39] Stam, W., Arzlanian, S., \& Elfring, T.(2014). Social capital of entrepreneurs and small firm performance: A metaanalysis of contextual and methodological moderators. Journal of Business Venturing, 29(1), 152-173.

[40] Teece, D. J.(2007). Explicating dynamic capabilities: the nature and microfoundations of (sustainable) enterprise performance. Strategic management journal, 28(13), 13191350.

[41] Tenenhaus, M., Vinzi, V. E., Chatelin, Y. M., \& Lauro, C.(2005). PLS path modeling. Computational statistics \& data analysis, 48(1), 159-205.

[42] Weerawardena, J.(2003), "Exploring the role of market learning capability in competitive strategy," European Journal of Marketing, 37(3/4), 407-429.

[43] Wernerfelt, B.(1984). A Resource-Based View of the Firm, Strategic Management Journal, 5(2), 171-180.

[44] Wiklund, J., \& Shepherd, D.(2003). Knowledge-based resources, entrepreneurial orientation, and the performance of small and medium-sized businesses Strategic Management Journal, 24(13), 1307-1314.

[45] Wiklund, J., \& Shepherd, D.(2005). Entrepreneurial orientation and small business performance: a configurational approach, Journal of Business Venturing, 20(1), 71-91.

[46] Yun, Lee, Lee(2012). Entrepreneurial Orientation and Firm Performance of Korean Business Ventures: Moderating Effects of Industry Dynamism and Alliance Diversity, The Journal of Small Business Innovation, 15(2), 23-44. [47]

[47] Yun(2014). A Meta Analysis of Entrepreneurial Orientation, Journal of Strategic Management, 17(3), 19-40.

[48] Yun(2015). A Theoretical Review of Research on Entrepreneurial Orientation, Asia-Pacific Journal of Business Venturing and Entrepreneurship, 10(5), 45-62.

[49] Zahra, S. A., \& Covin, J. G.(1995). Contextual influences on the corporate entrepreneurship-performance relationship: A longitudinal analysis. Journal of business venturing, 10(1), 43-58.

[50] Zahra, S. A.(1996). Governance, ownership, and corporate entrepreneurship: The moderating impact of industry technological opportunities. Academy of management journal, 39(6), 1713-1735.

[51] Zhou, K. Z., Yim, C. K., \& Tse, D. K.(2005). The effects of strategic orientations on technology-and market-based breakthrough innovations. Journal of marketing, 69(2), 4260.

[52] Zhou, K. Z., Yim, C. K., \& Tse, D. K.(2005). The effects of strategic orientations on technology-and market-based breakthrough innovations. Journal of marketing, 69(2), 4260. 